\title{
DOCUMENTOS
}

\section{NOTICIAS SOBRE TRES PINTORES DE LA ÉPOCA COLONIAL}

\section{Mina Ramírez Montes}

El primer artista que ocupará nuestra atención es el famoso pintor y retablista sevillano Andrés de Concha, pero en este caso no nos referiremos a los oficios que le dieron lustre, sino a la dirección de obras de cantería, trabajos que más tarde se denominarían de arquitectura. Cabe aclarar que el término arquitecto, como actualmente lo conocemos, no tenía el mismo significado en la Nueva España del siglo xvi, entonces se llamaba así a los teóricos del arte de la construcción y a los grandes conocedores del dibujo y la perspectiva. Baste recordar los escritos de Cervantes de Salazar, quien al referirse a Claudio de Arziniega como autor del túmulo del emperador Carlos V, lo llama "arquitecto excelente", 1 y no porque realizase un edificio, sino por la traza y modelo que hizo para el catafalco. En cambio los títulos que Arziniega recibió por su obra constructiva fueron los de cantero, maestro de obras y obrero mayor de la Nueva España. ${ }^{2}$

Sabemos que Andrés de Concha obtuvo el permiso para pasar a América en enero de 1568, habiendo llegado a México quizás en el mismo año para cumplir con un contrato realizado en la península, el cual se Ilevaría a efecto en la iglesia dominica de Yanhuitlán, Oaxaca. ${ }^{3} \mathrm{Al}$ término de éste, decidió quedarse en la Nueva España y hacerse de nuevos compromisos que lo mantuvieran en esta tierra.

Su habilidad en el manejo del pincel le valió no pocas alabanzas de sus contemporáneos y loables críticas, aunque no exentas de polémica, de los historiadores del arte de nuestro siglo, por lo que no seremos reiterativos en ese aspecto de su obra, en cambio, trataremos de aclarar una duda: la participación de De Concha en una iglesia de Guadalajara, que habia sido planteada por Guillermo Tovar de Teresa en su Pintura escultura del Renacimiento en México, ${ }^{4}$ y retomada sin solución, por

1 Cervantes de Salazar, Francisco, México en 1554 y Túmulo imperial, ed. y pról. de Edmundo O’Gorman. México, Editorial Porrúa, 1963 (col. Sepan cuántos..., 25).

2 Marco Dorta, Enrique, Fuentes para la historia del arte hispanoamericano, Sevilla, Escuela de Estudios Hispanoamericanos, 1951, vol, I, pp. 232-245.

3 Marco Dorta, Enrique, "Noticias sobre el pintor Andrés de Concha", en Archivo español de arte, núm. 199, 1977, pp. 343-345.

4 Tovar de Teresa, Guillermo, Pintura y escultura del Renacimiento en México, pról. de Diego Angulo. México, Instituto Nacional de Antropología e Historia, 1979. 
José Guadalupe Victoria en su artículo sobre este pintor. ${ }^{5}$ La localización de dos cartas referentes a la solicitud de De Concha, para ocupar la dirección de la catedral de Guadalajara, en 1599, nos pusieron en este camino. ${ }^{6}$

La primera piedra de la iglesia episcopal de la Nueva Galicia, fue colocada en 1571, y para 1618 estaba casi terminada. ${ }^{7}$ El autor del trazado todavía permanece desconocido, pues según sabemos Martín Casillas, a quien algunos se lo atribuyen, se ocupó de la obra después del año de 1585, y en 1599, denunció algunos errores en la construcción. Fue entonces, cuando Diego de Aguilera maestro mayor de la Catedral de México, por petición de la Audiencia de Guadalajara, dio su parecer al respecto y propuso que la obra se diera a destajo, exponiendo las ventajas de ello. Él mismo presentó una postura y por ser más baja que la de Cásillas, le fue concedida. ${ }^{8}$ Hubieron además otros opositores, puesto que el rematé se pregonó en las ciudades de México, Puebla, Valladolid y Zacatecas, entre ellos se menciona al "desconocido Solano" y a De Concha de quien se sabían sus habilidades de " ... buen pintor y escultor de imágenes y retablos..." 9 Los postores no conformes, apelaron ante la Audiencia, De Concha y Sebastián Solano, quienes parece trabajaron mancomunadamente en este proyecto, ${ }^{10}$ mejoraron la oferta de Aguilera, pero según percibimos por la segunda carta, los elogios fueron para el último, de quien se "... sabe cuán hombre de bien y cuán buen artífice es y las obras que tiene a su cargo...", en cambio de Solano no se sabía que fuera "oficial famoso" y De Concha era menos. preciado porque no prometía conocer "... de levantar paredes de cal y canto, de bóvedas, de mezclas, ni de carpintería...", defectos que hicieron desistir a la Audiencia, de concederles tal privilegio ${ }^{11}$ Por su parte, Martín Casillas expuso, con lujo de detalles, lo conveniente de

5 Victoria, José Guadalupe, "Sobre las nuevas consideraciones en torno a Andrés de la Concha”. Anales del Instituto de Investigaciones Estéticas, UNAM, 1982, p. 82. 6 Véase docs. núms. 1 y 2.

7 Angulo Íñiguez, Diego, Historia del arte hispanoamericano, 3v. Barcelona, Salvat editores, 1945, vol. 1, pp. 438-439.

8 Marco Doxta, E., Fuentes..., vol. I, pp. 186-188.

9 Véase doc núm, 1 .

10 Poder otorgado por Andrés de la Concha y Sebastián Solano maestros de arquitectura y geometria a González Calderón o a Gerónimo Conde alguacil mayor de Guadalajara, para que haga baja a la postura que ambos hicieron para construir la catedral del obispado de la Nueva Galicia.

Archivo General de Notarías Cd. de México, 22 de agosto de 1599, Notario: Juan Pérez de Ribera.

11 Véase doc. nứm. 2, 
su proyecto y después de un litigio corto, le fue adjudicada la obra nuevamente, quien la continuó hasta fenecerla. ${ }^{12}$

El deseo de Andrés de Concha por inmiscuirse en construcciones catedralicias, o por falta de contratos del arte que dominaba, le hicieron oponerse, por las mismas fechas, a la maestría de la Catedral de México, esta vez corrió con mejor suerte, pues aunque se tornó a insistir en su carencia de conocimientos sobre la cantería, se le concedió intèrinamente el nombramiento. ${ }^{13}$

El siguiente documento que aquí presentamos, alude a la participación del pintor José de Ibarra en la decoración del máximo templo angelopolitano. Este manuscrito forma parte del Libro de fábrica de esa catedral, correspondiente al año de 1732. ${ }^{14}$ Ibarra nació en la ciudad de Guadalajara en el año de 1688 y falleció en la de México, sesenta y ocho años después.

La crítica a su producción pictórica fue muy elogiosa por parte de sus contemporáneos, no así la de los historiadores del arte, quienes lo han considerado como un hombre talentoso, pero falto de carácter para hacer de sus obras verdaderas creaciones artísticas. ${ }^{15}$ No cabe duda que el tiempo no solamente cambia las costumbres, sino que también modifica los criterios, es así como en el siglo $\mathrm{xx}$, tanto su vida personal como su obra han sido juzgadas severamente. ${ }^{16}$ Nosotros no entraremos en más detalles, ni mencionaremos los pocos lienzos salidos de su pincel, que hasta la fecha se conocen, pues de esto se han encargado los colegas, que con muchos años de labor y de sentido crítico nos han precedido, nos referimos a Manuel Toussaint y su obra Pintura colonial en México, y a las notas que para esa misma escribió Xavier Moyssén, además de los artículos que recientemente ha publicado este último.

Al darnos cuenta que sus pinturas no han sido del todo identificadas, por lo difícil que resulta catalogar obras de caballete, que tan fácilmente cambian de sitio y de propietario, decidimos dar a conocer el testimo. nio que ampara la cantidad de trescientos veintiséis pesos de oro común,

12 Marco Dorta, E., Fuentes..., vol. I, pp. 188-195.

13 Archivo General de Indias, Audiencia de México, leg. 24, núm. 62.

14 Véase doc. núm. 3 .

15 Toussaint, Manuel, Pintura colonial en México. México, Universidad Nacional Autónoma de México, 1982, p. 156

16 Moyssén, Xavier, "La pintura del siglo xvir" en Historia del arte mexicano. México, Editorial Salvat, 1982, tascículos núms. 53-54, y "El testamento de José de Ibarra", en Monumentos históricos, Boletin del Instituto Nacional de Antropologia e Historia, 1981, núm. 6, pp. 41-52. 
que recibió Ibarra por pintar cuatro lienzos para la Catedral de Puebla. Sentimos mucho que esta fuente no sea tan cristalina como lo hubiéramos deseado, es decir, que su contenido sirviera para aclarar una duda en el conocimiento de Ibarra, y no para sembrar otra, de la cual nosotros hemos sido los primeros desconcertados. Toussaint dice, que Revilla menciona los siguientes cuadros de Ibarra en la citada catedral: " . . . una Asunción, un San Miguel ofreciendo el templo de la Virgen, y otros [no dice cuántos] alegóricos." 17 Por su parte, Moyssén cita dentro de la misma iglesia estos cuatro: Los desposorios, La Asunción, San Miguel y un San José dando gracias. ${ }^{18}$ Como puede colegirse, entre ellos sólo dos temas coinciden, a menos que a Revilla le parecicran "alegóricos", los asuntos josefinos.

Moyssén, de quien tenemos certeza que no cita de "oídas", sino de "vista", y quien además fecha éstos en 1732, nos parece del todo confiable. Sin embargo, existe discrepancia entre su aseveración y el documento presentado, pues en este último se asienta que fueron cuatro lienzos que representaban: “...las imágenes del Santisimo Sacramento, de Jesús Niño, de la Santisima Virgen de la Concepción, y de La Asunción, con varios santos canónigos en ademán de adorarles..." Que finalmente haya cambiado de parecer el contratante no es creíble, pues este documento es sólo un testimonio del recibo que había sido otorgado con anterioridad por el pintor, por tanto su trabajo debió haberse concluido cuando se le entregó el último real, pues con aquello de que "música pagada toca mal son", ningún mayordomo de fábrica se atrevía a remunerar totalmente al obrero, sin que éste hubiera terminado su trabajo, antes bien el contratado se obligaba a entregar la obra sin costo. en caso de no cumplir en la fecha prevista. Entonces, ¿qué habrá pasado?, somos de la opinión que existen más de cuatro lienzos de Ibarra en la Catedral de Puebla y que algunos de los temas mencionados en el recibo, corresponden a los cuadros que se localizan en el exterior del coro y que tal vez no llevan la rúbrica del autor por lo que no habían sido identificados como suyos. El despeje de esta incógnita lo dejaremos a futuros investigadores en la materia, o a nosotros mismos para mejor ocasión. A pesar de la interrogante que este manuscrito plantea, su contenido no deja de tener importancia, así lo hemos creído y por ello lo damos a conocer.

17 Toussaint, M., op. cit, p. 158.

18 Moyssén, X., "La pintura del siglo xvuı", p. 60. 
Nuestro cuarto y último documento, ${ }^{19}$ aporta datos interesantes de la vida y obra del pintor italiano José Perovani, quien vivió en México a principios del siglo xIx. Las únicas obras que de él se conocen son los retratos de los virreyes Calleja y conde Del Venadito. ${ }^{20}$

En 1954, José Torre Revello publicó un extracto del memorial preparado por Perovani, mediante el cual el pintor solicitaba al rey, le fuera concedido permiso a él y a su esposa, para permanecer en el reino de la Nueva España. La resolución afirmativa del Consejo de Indias está fechada en 19 de diciembre de 1804. ${ }^{21}$ En julio del año siguiente, el rey expidió su real cédula a las autoridades novohispanas, para que permitieran la estancia solicitada, es ésta precisamente la que nosotros hemos localizado en el Archivo General de la Nación, la cual confirma los datos publicados por Revello, puesto que las cartas reales transcribían o sintetizaban la solicitud del interesado, y abunda en el conocimiento de nuestro personaje.

Al emigrar Perovani de su patria se refugió en Filadelfia, donde se dio a conocer "... con las obras practicadas en la iglesia de los católicos y en un coliseo magnífico". Luego pasó a La Habana, ahí trabajó para la catedral y más tarde a la ciudad de Veracruz, donde colaboró en varias obras públicas y particulares que no se especifican. ${ }^{22}$

Toussaint analiza su obra y concluye, "... que no fue un artista extraordinario, sino que siguió la misma modesta ejecución que se estilaba en ese tiempo en México". ${ }^{23}$ Seguramente que esos dos cuadros, de que tenemos noticia, no son los únicos de Perovani. Una búsqueda acuciosa en los archivos y en las pinacotecas particulares, podrían arrojar luz en la obra de éste y otros artistas. Estos documentos son sólo una pequeña aportación de lo mucho que hay por hacer en este campo.

19 Véase doc. núm, 4 .

20 Toussaint, $\mathrm{M}_{\text {", }}$ op. cit, p. 210.

21 Torre Revello, José, "Datos relacionados con las artes plásticas". Anales del Instituto de Arte Americano e Investigaciones Estéticas. Buenos Aires, núm. 7, 1954, p. 135 .

22 Véase doc. núm. 4.

23 Toussaint, $\mathbf{M}_{\text {, }}$ op. cit., p. 210. 


\section{DOCUMENTO $\mathrm{N}^{\circ} 1 *$}

Carta del virrey conde de Monterrey al presidente de la Audiencia de Guadalajara.

Cd. de México, 27 de julio de 1599.

La obra de la iglesia de esa catedral se trujo en pregones en esta ciudad y en la de los Ángeles, en conformidad de la provisión de esa Audiencia y resultó lo que vuestra merced verá por las diligencias originales. ${ }^{24}$

Tengo por conveniente el mirar bien la persona en quien se hubiere de rematar, porque Solano no sé que sea oficial famoso, ni que haya tenido o tenga a cargo obras grandes. $\mathrm{Y}$ al Concha, tengo yo por buen pintor y escultor de imágenes y retablos, aunque es verdad que de ambos tengo poca noticia, podrá ser que allá le haya de hallar o que haya personas que las conozca mejor, de quien podrá vuestra merced informarse más particularmente, para tomar resolución.

Guarde Dios vuestra merced.

En México, a 27 de julio de 1599.

El conde de Monterrey [rúbrica]

\section{DOCUMENTO No 2 *}

Carta de Eugenio Salazar, oidor de la Audiencia de México, al doctor Santiago de Vera del Consejo de su majestad y presidente y gobernador de la Audiencia de Guadalajara.

Cd. de México, 3 de agosto de 1599.

[capitulo tercero].

Aguilera me parece tiene puesta y rematada la obra de esa iglesia y díceme que Concha, un pintor, ha hecho cierta baja, y como vuestra

* Biblioteca Pública del Estado de Jalisco Sección manuscritos, Documento procedente del Supremo Tribunal de Justicia del Estado (microfilm, rollo 2 de Guadalajara, en Biblioteca Nacional de Antropologia e Historia).

24 Marco Dorta, E, Fuentes..., vol i, pp. 172-195. 
señoría mejor sabe, no porque uno baje se le ha de dar lo que se remata si es menos conveniente que el que baja menos. Yo no sé el pintor que puede saber de levantar paredes de cal y canto, de bóvedas, de mezclas, ni de carpintería tradent fabriliae fabri. Aguilera, vuestra señoría le conoce muchos años ha y sabe cuán hombre de bien y cuán buen artifice es y las obras que tiene a su cargo y así será justo vuestra señoría no permita se le haga agravio ni le reciba la obra de esa santa iglesia.

México, agosto 3 de 1599.

El doctor Eugenio de Salazar [rúbrica]

\section{DOGUMENTO NO $3 *$}

Testimonio del recibo otorgado por José de Ibarra maestro de pintor, a Gaspar Antonio Méndez de Cisneros tesorero de la catedral de Puebla.

Cd. de México, 24 de octubre de 1732.

En la ciudad de México, a veinticuatro días del mes de octubre de mil setecientos y treinta y dos años, ante mí el escribano y testigos, don Joseph de Ibarra maestro del arte de pintor, vecino de esta ciudad, que doy fe conozco, otorga haber recibido del señor doctor don Gaspar Antonio Méndez de Cisneros, prebendado de la santa iglesia catedral de la ciudad de la Puebla de los Ángeles y tesorero de la fábrica material de ella, la cantidad de trescientos veinte y seis pesos de oro común en reales, por otros tantos, que han tenido de costo, los cuatro lienzos de a tres varas y media, cada uno, y dos y media de ancho, en que están representadas las imágenes del Santísimo Sacramento, de Jesús Niño, de la Santísima Virgen de la Concepción y de La Asunción, con varios santos canónigos en ademán de adorarlas. Con declaración que en dicha cantidad se incluye el costo de los cuatro lienzos aparejados y sus conducciones de ésta a aquella ciudad, incluyéndose en esta misma cantidad, la que en otro recibo del costo de los dos primeros lienzos, de los cuatro en este contenido, tiene otorgado el dicho don Joseph de Ibarra, quien como entregado de dicha cantidad, a su voluntad, renuncia la excepción de pecunia leyes de la entrega, prueba y demás del caso, y le otorga

* Archivo General de la Nación. Reales cédulas duplicados, v. 193. 
recibo y carta de pago en toda forma y con los requisitos en derecho necesarios, para que se le pase en cuenta en la que diere y fuere de su cargo.

Y lo firmó, siendo testigos Joseph Flores, Bernardino Garnica y Antonio de Marchena vecinos de esta ciudad. Joseph de Ibarra. Ante mí Felipe Muñoz de Castro escribano real. Sacóse día de su otorgamiento para la parte a quien se entregó, doy fe.

En testimonio de verdad hago mi signo.

[signo]

Felipe Muñoz de Castro escribano real [rúbrica]

\section{DOCUMENTO No $4^{*}$}

Real cédula, mediante la cual se permite a José Perovani y a su esposa, permanecer en el reino de la Nueva España.

Aranjuez, $1^{\circ}$ de julio de 1805 .

El Rey

Por cuanto don José Perovani, italiano de nación, profesor de pintura histórica, retratista y teatral, hallándose con su mujer en la ciudad de Veracruz, de la Nueva España, me hizo presente, que establecido en Roma con aplauso de su arte, el temor de la guerra con los franceses, le hizo abandonar su taller y comodidades, y en el año de 1794 pasó a Filadelfia, en donde se dio a conocer con las obras practicadas en la iglesia de los católicos y en un coliseo magnífico. Que llamado después a La Habana por el gobernador don Luis de las Casas, logró la protección de sus sucesores en el mando, conde de Santa Clara y marqués de Someruelos, por la conducta arreglada que observaron, así él como su mujer. Que ésta estableció allí con licencia del Gobierno, una academia para las jóvenes que quisieran instruirse gramaticalmente en los idiomas, francés, inglés e italiano, pintar, escribir, contar, bordar y otras artes, cuyos progresos vio con admiración aquel país. Pero como a los cinco años de residir en él, hubiesen pasado a la misma ciudad de La Habana

* Archivo General de la Nación. Reales cédulas duplicados, v. 172, f. 159-160. 
las monjas ursulinas, que por su instituto se ocupan en enseñar muchas de las cosas indicadas, considerando que la enseñanza que daba su mujer, no tendría igual efecto, determinó trasladarse a Veracruz y después a México, en donde como ciudad populosa y la principal del reino, podrían sus habitantes satisfacer los deseos de la instrucción de sus niñas, y él, auxiliado de su profesión, vivir con la tranquilidad que perdió desde que salió de su patria, comprobando con una certificación del Ayuntamiento de Veracruz, la arreglada conducta que habian observado allí y la singular habilidad de Perovani acreditada en varias obras públicas y particulares que le habían conciliado la común estimación, en términos que aquel cuerpo les consideraba dignos de mi real acogida y protección. $\mathrm{Y}$ hecho cargo el mismo interesado de que las leyes prohibian permanecer en mis dominios de América, sin la correspondiente real licencia, me suplicó que dispensándolas me dignase concederles la gracia de poder vivir, con su mujer, libremente en ellos.

Vista esta instancia en mi Consejo de las Indias (adonde tuve a bien remitirla con real orden de 15 de octubre del año último), lo que en su inteligencia expuso mi fiscal. $\mathrm{Y}$ habiéndome consultado sobre ello en 14 de diciembre siguiente, no obstante, que el don José Perovani carece de los requisitos prevenidos por las leyes, para haber pasado y permanecer en las Indias, disponiendo la [ley] diez, título siete, libro nueve, que la expulsión de los extranjeros no se entienda con los que sirvan oficios mecánicos, útiles a la república, con tal que guarden la integridad de nuestra santa fe católica, porque la principal prohibición comprende a los tratantes y a los avecindados en pueblos particulares, especialmente marítimos.

He resuelto tolerar, por ahora, a dicho extranjero Perovani, que resida con su mujer en la ciudad de México ejerciendo su arte, mientras observe una conducta arreglada, cual corresponde, y bajo de la calidad de que haya de prestar el debido juramento de fidelidad y obediencia, a mí y a las leyes, y de proceder en todo, arreglado a estas obligaciones (sobre que encargo a mi virrey de Nueva España cuide de ello, por medio de los alcaldes del crimen y de cuartel para providenciar su expulsión de aquellos reinos, ocupación de bienes y demás que haya lugar en su caso, conforme a las leyes), hasta que con el tiempo pueda adquirir las calidades necesarias para la naturalización que deberá solicitar con la justificación prevenida, por la que tratan del particular.

Por tanto, por esta mi real cédula, ordeno y mando al expresado mi virrey de Nueva España, a mi Real Audiencia de México y a los demás 
jueces y justicias, a quienes corresponda, guarden y cumplan y hagan guardar y cumplir la mencionada mi real resolución y que hecho por Perovani el indicado juramento de fidelidad y cumpliendo con las demás obligaciones que quedan referidas, no le impidan su residencia en aquel reino, ni le molesten por calidad de extranjero, pues así es mi voluntad.

Fecha en Aranjuez, a 16 de febrero de 1805.

Yo el rey

Por mandado del rey nuestro señor Antonio Porcel

Señalada con tres rúbricas.

Decreto [al margen].

México, $1^{\circ}$ de julio de 1805 . Guárdese y cúmplase lo que su majestad manda en esta real cédula y asentada en los libros de superior gobieno a que toca. Sáquese testimonio de ella y con los antecedentes que hubiere pásese al señor fiscal de lo civil.

José de Iturrigaray 